\title{
FRAY FRANCISCO MARÍN: VIGNOLA'S RIVAL IN THE NEW WORLD
}

ROBERT MULLEN

What can be gleaned from documents about the Dominican priest known as Fray Francisco Marín, active in Mexico in the sixteenth century? Only two salient facts: first, that he was an architect; second, that he was a very busy friar.

Fray Agustín Dávila Padilla, also a Dominican, completed his history of the Dominican Province of Santiago, Mexico, in 1592. Therein he described Fray Francisco Marín as one who, with the skill of an architect, drew plans for their churches and residences and served as overseer in them when so engaged. ${ }^{1}$ Unfortunately Dávila Padilla supplies no specifics. Fortunately another source does.

From the official records, known as the actas, ${ }^{2}$ of the periodic chapter meetings held by the Dominicans of the Province of Santiago, Mexico, a certain friar had, within a fifteen-year period, nine assignments. This was highly unusual since assignments to a pueblo as a parish priest were normally for a long time, sometimes for life. Furthermore these nine assignments ${ }^{3}$ between 1541 and 1556 were closely linked to other church related events sufficiently significant to the Province to be recorded in the actas. This "certain friar" was none other than Fray Francisco Marín. What was this peripatetic friar doing? Evidently "drawing up plans of churches and overseeing their execution." Of immediate interest is the fact that in a four year span - between 1546 and 1550 - Fray Francisco was assigned to three places: Yanhuitlán, Coixtlahuaca, and Oaxaca.

\footnotetext{
${ }^{1}$ Dávila Padilla, Agustín. Historia de la fundación y discurso de la Provincia de Santiago de México de la Orden de Predicadores... de Nueva España, México, 1955, 238-244 ("Trazábales las iglesias y casas de comunidad como arquitecto, y serviales en ellas de mayordomo cuando daban lugar las ocupaciones...").

${ }^{2}$ These actas were analyzed extensively in Dominican Architecture of Sixteenth-Century Oaxaca, Tempe, Arizona, 1975, Chapter 3 . Since its publication more intensive analyses of Oaxaca's architecture and sculpture have been made. In this article the singular accomplishments of one of the few identified colonial architects, also a Dominican, is developed.

${ }^{3}$ Fray Francisco Marin's nine assignments were: 1541 - Teposcolula; 1546 - Coixtlahuaca; 1547 - Oaxaca; 1548 - Teposcolula; 1550 - Yanhuitlán; 1552 - Izúcar; 1553 - Teposcolula; 1555 - Tonalá; 1556 - Chila; 1559 - deceased.
} 


\section{Santo Domingo Yanhuitlán}

In 1548 the Dominicans officially assumed responsibility for the spiritual welfare of Yanhuitlán and its many dependencies. It can be inferred that the present church and convento of Santo Domingo were then begun since, only ten years later, in 1558, Santo Domingo hosted a chapter meeting (with some 50 friars in attendance) ${ }^{4}$

The Order had actually committed itself to Yanhuitlán as early as 1538. However, because of a rift between the encomendero of Yanhuitlán and the Order, those friars assigned there in 1538 were not permitted to take up residence. Instead they went to nearby Teposcolula, also officially "accepted" by the Dominicans in 1538. Among them may have been Fray Francisco Marin as he is documented in Teposcolula in 1541. During his stay in that pueblo he would have had ample time to draw up the plan for Santo Domingo (fig. 1), whose construction he surely supervised when assigned to Yanhuitlán in 1550.

The exterior of the church measures 79 meters in length, 17.5 in width and 25 in height To its south lies the convento measuring 56 by 47 . The atrio, to the north of the church, has dimension of $120 \times 90$. To the west the atrio extends 35 meters beyond the plane of the facade . On its axis a flight of 28 balustered steps, 6.5 meters wide, leads up from the road to the level of the atrio.

The monolithic church occupies two-thirds of the atrio in its east-west axis. This stone complex, staggering in its size and made entirely of good dressed masonry, sits upon a raised terrain covering 24,000 square meters, much of it three to five meters above ground level.

Arising like a mirage from the mountain-surrounded valley, Santo Domingo rushes upon the traveller descending the twisting mountain road. The north nave wall (fig.2) is solid until the string course marking the spring of the vaults. Resting on this sill, four round-headed windows are centered between five buttresses. These rise to the uppermost reaches of the wall whose height (actually a parapet) conceals the vaults. Buttresses and string courses serve to create a series of 15 x 15-meter "panels", imposing in their starkness, pleasing in their proportions. On this north wall a handsomely sculpted portal occupies the entire second bay - Yanhuitlán's famous "north door" opens out into the atrio.

${ }^{4}$ Dominican Architecture, p 40 . Though secularized in 1810, Santo Domingo Yanhuitlán has, during these past 444 years (as of 1992), served continuously as a parish center. 


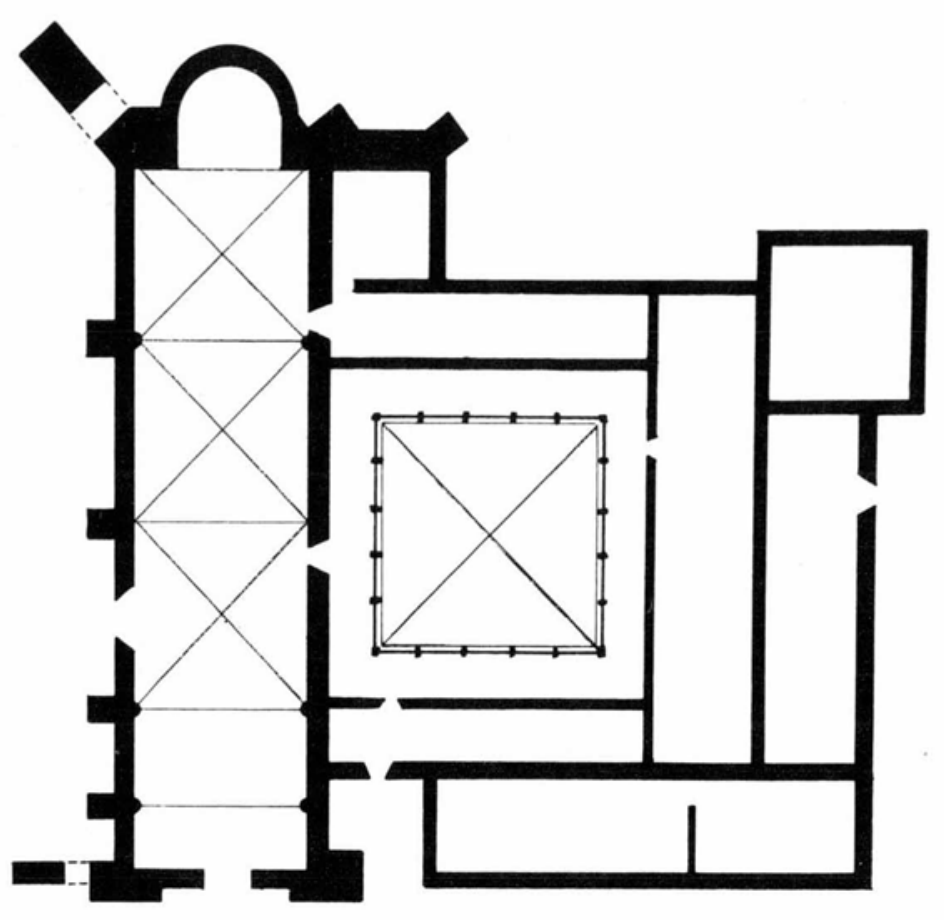

1. Santo Domingo Yanhuitlán. Plan. 
DOI: http://dx.doi.org/10.22201/iie.18703062e.1993.64.1670

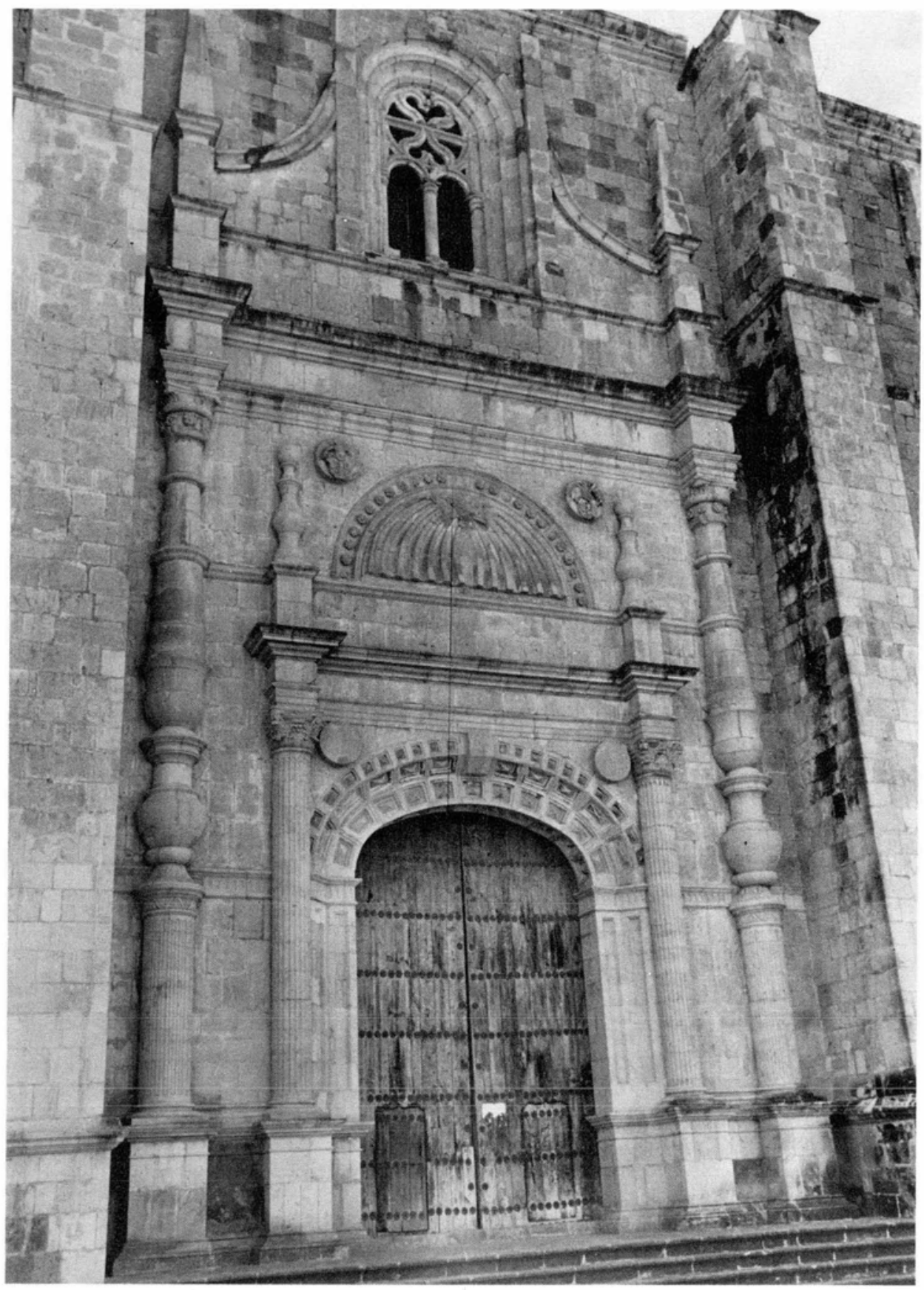

2. Santo Domingo Yanhuitlán: North nave wall, portal. 


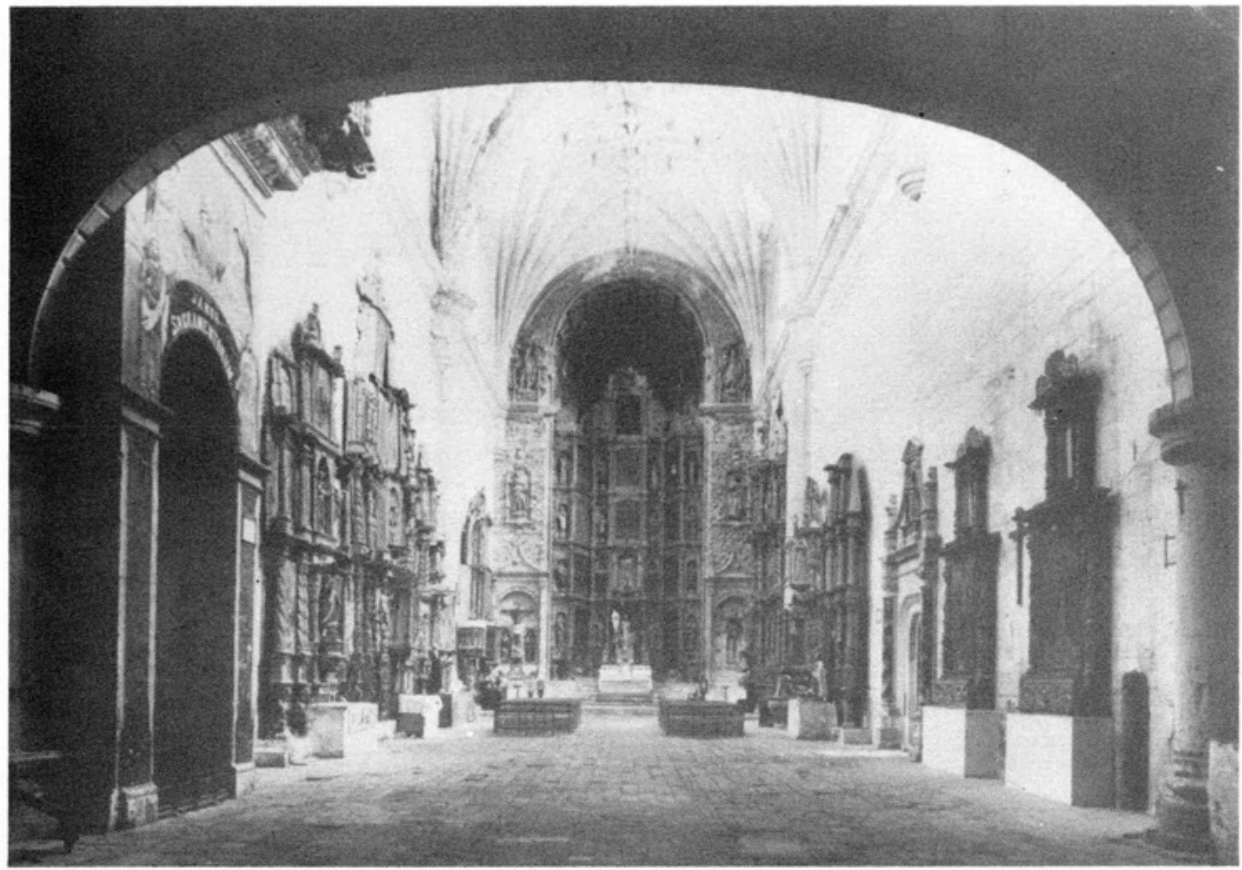

3. Santo Domingo. Yanhuitlán. Nave interior looking east towards sanctuary.

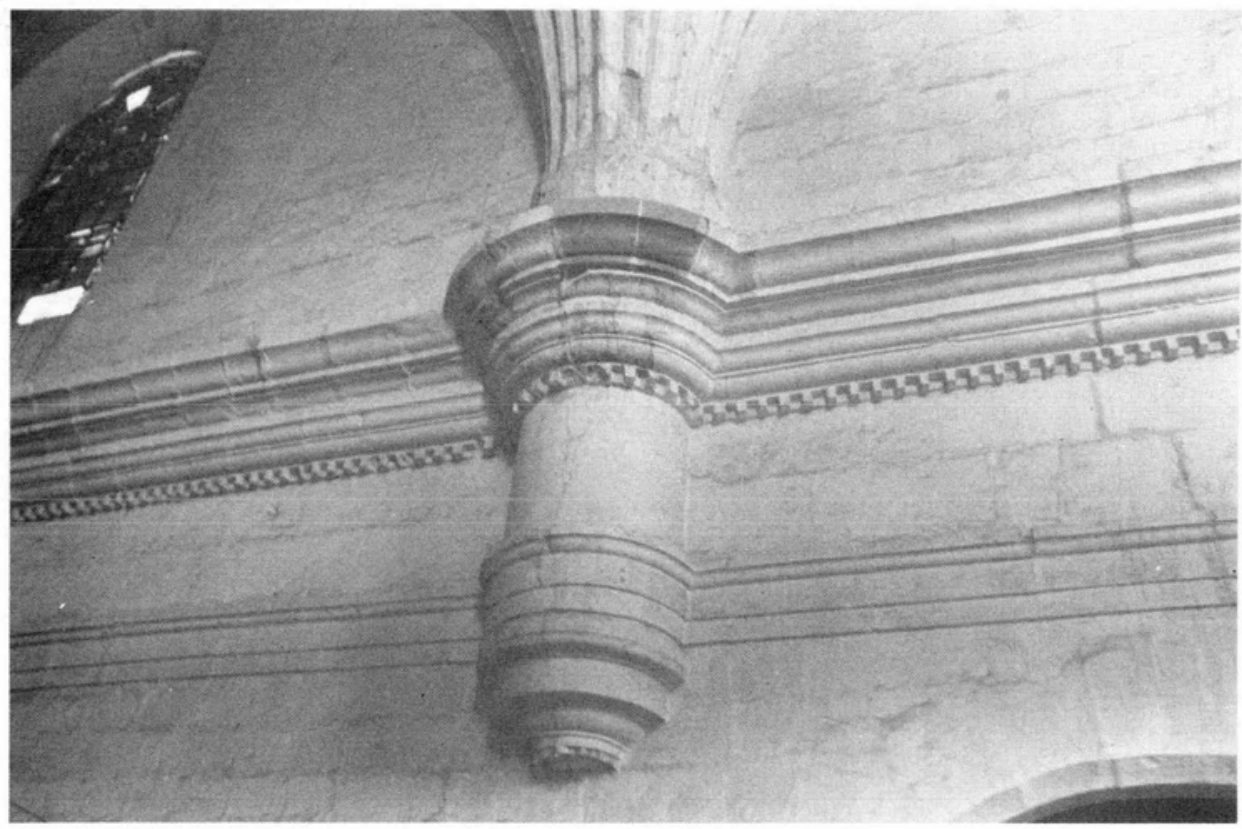

4. Santo Domingo Yanhuitlán. "Dominican corbel". 


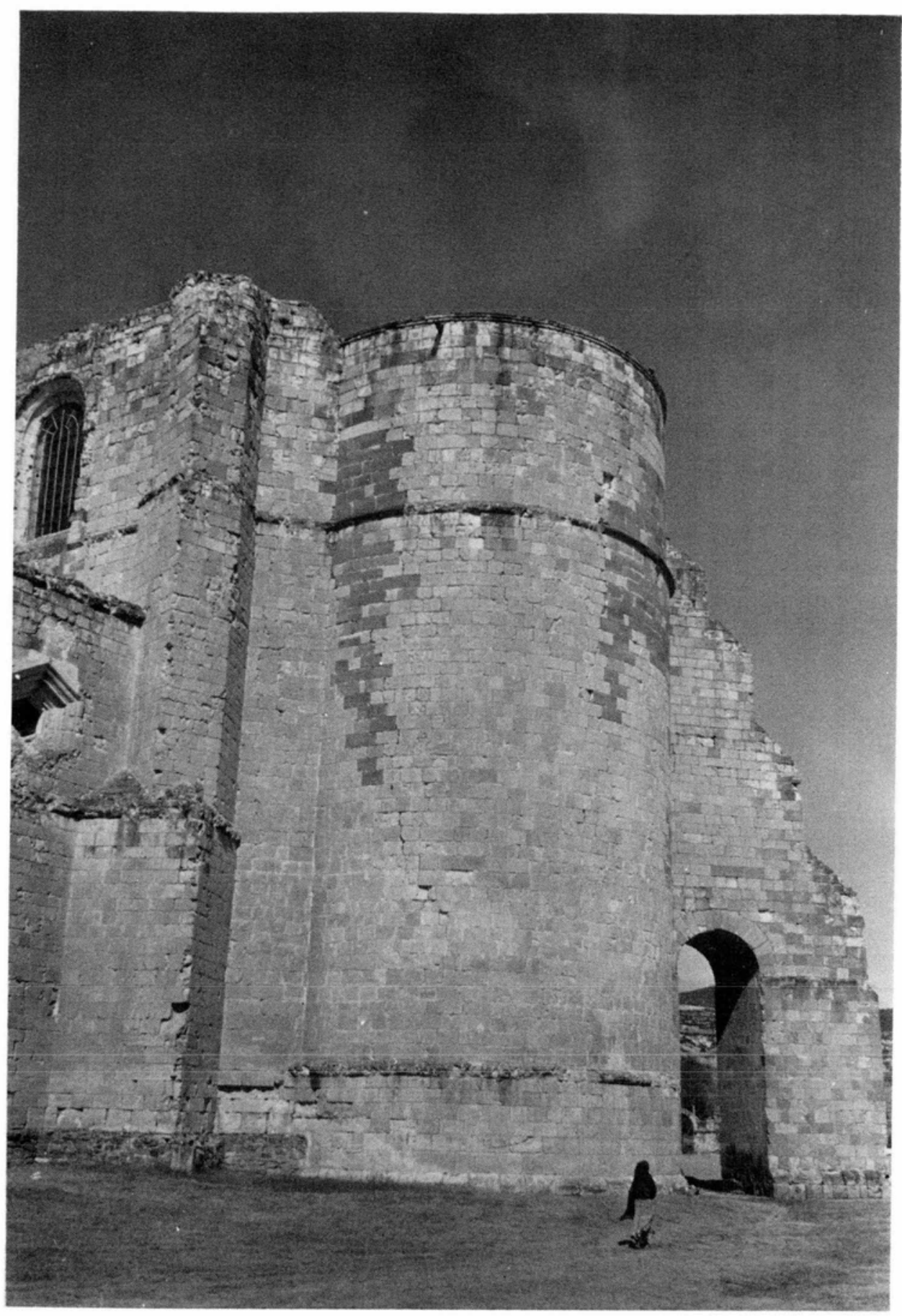

5. Santo Domingo Yanhuitlán. Radial apse. 
DOI: http://dx.doi.org/10.22201/iie.18703062e.1993.64.1670

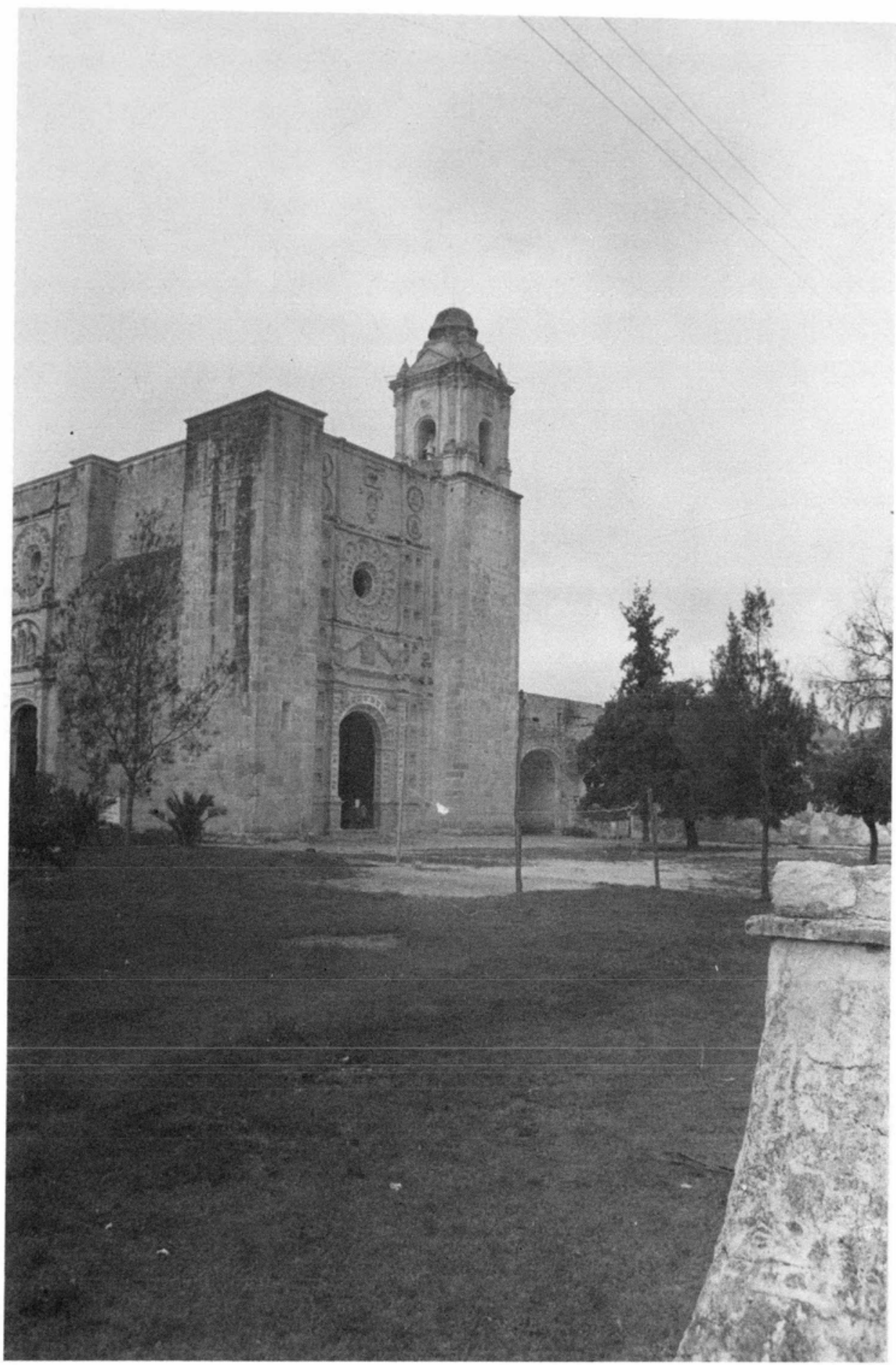

6. San Juan Bautista Coixtlahuaca. West front, facade. 


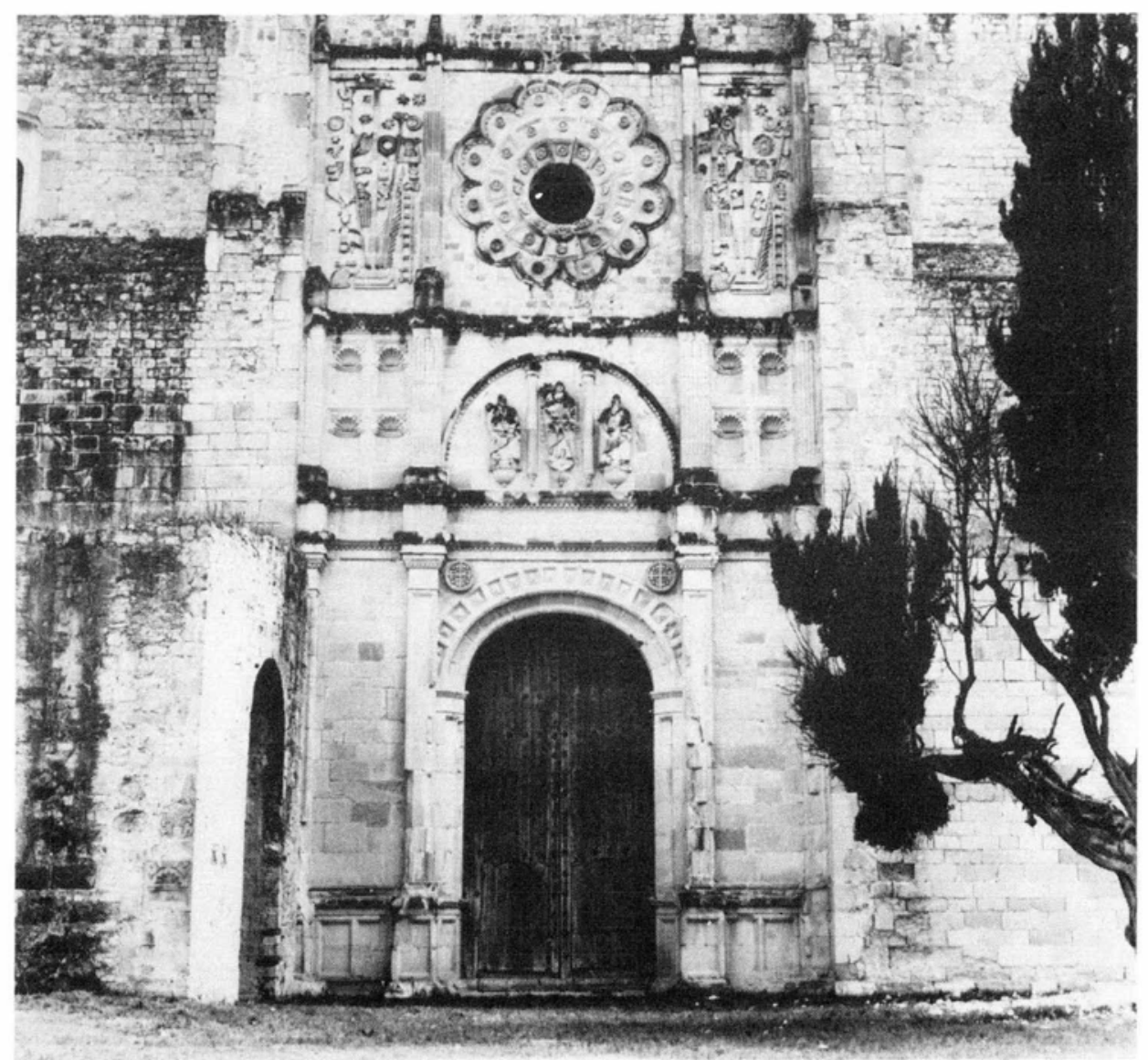

7. San Juan Bautista Coixtlahuaca. North door. 


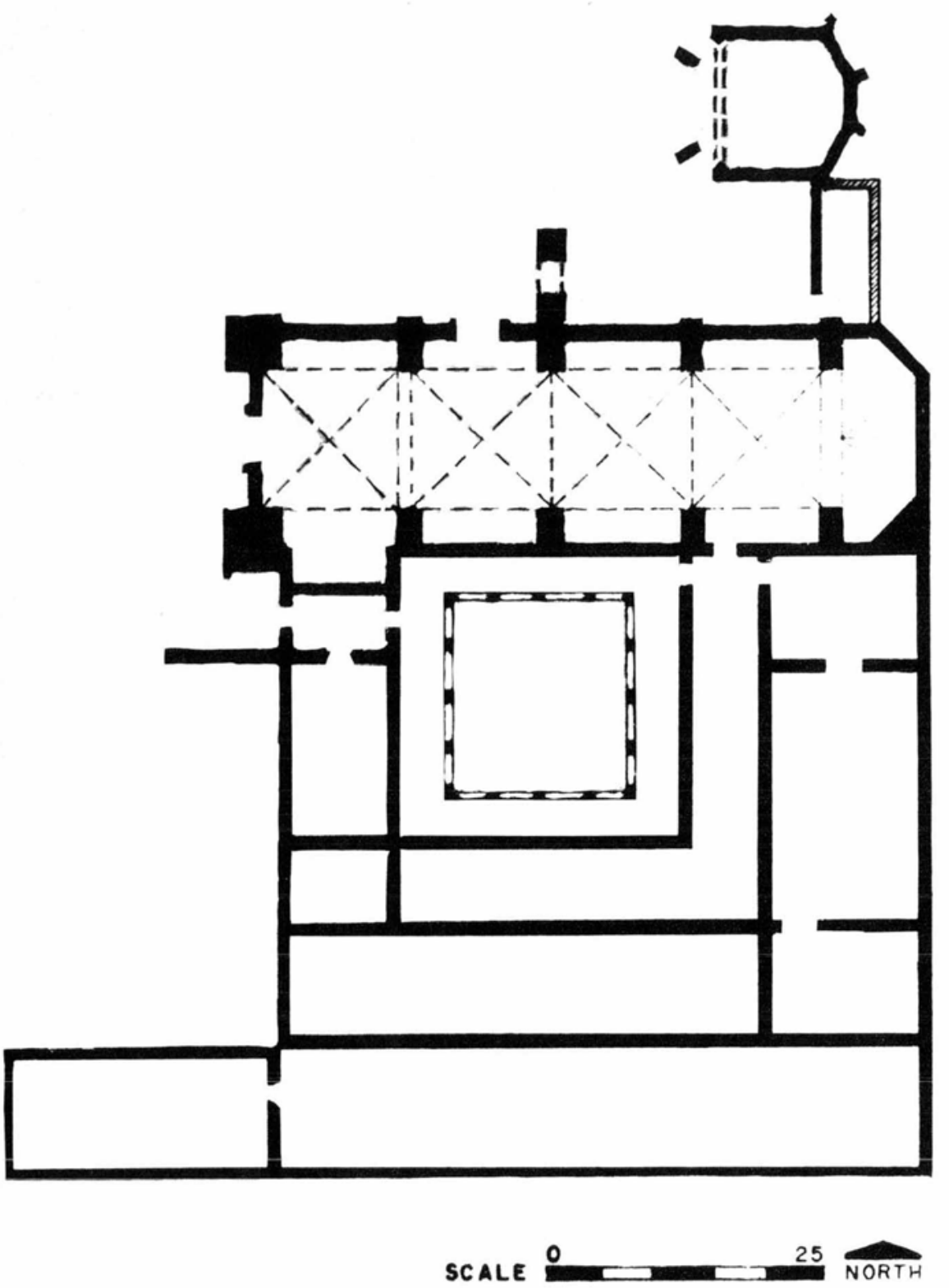

8. San Juan Bautista Coixtlahuaca. Plan 


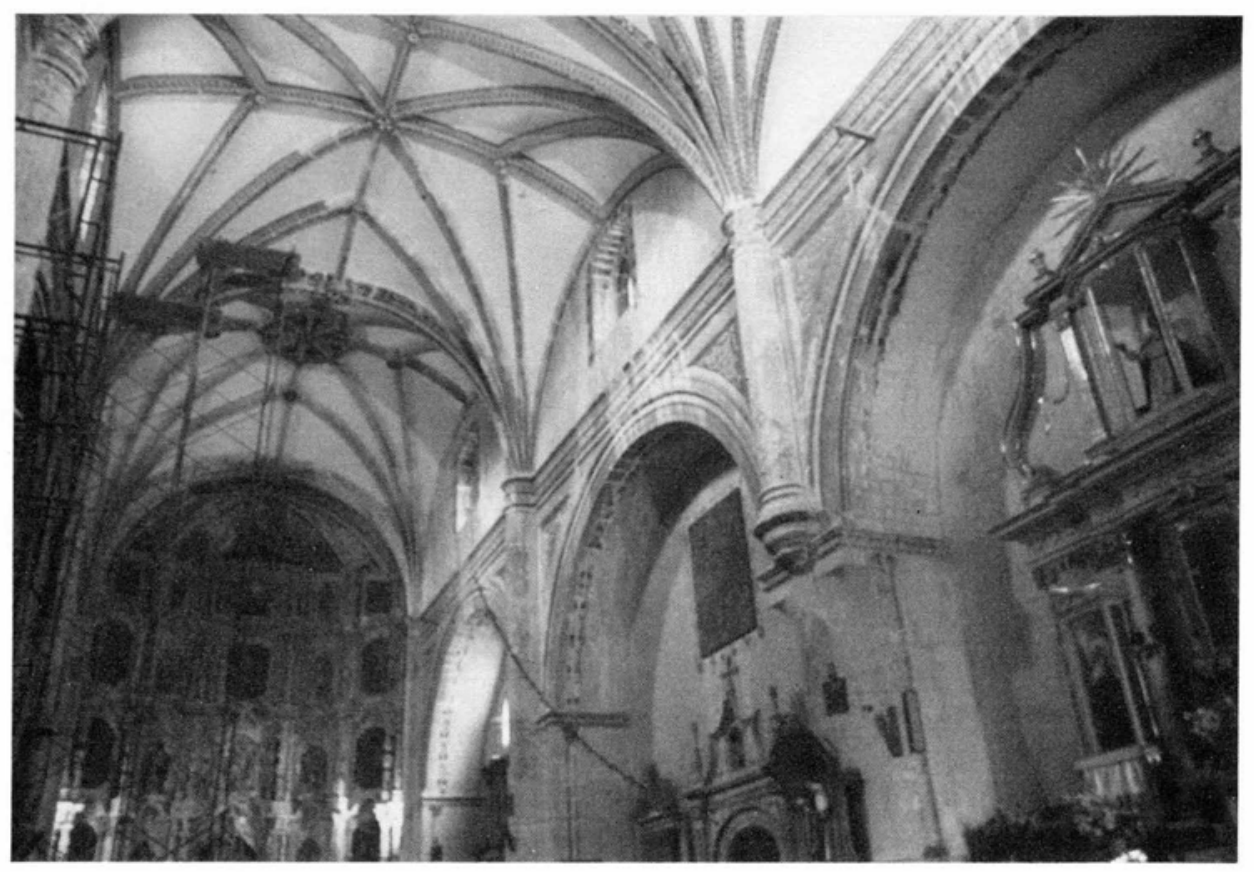

9. San Juan Bautista Coixtlahuaca. Nave interior looking east towards sanctuary. 

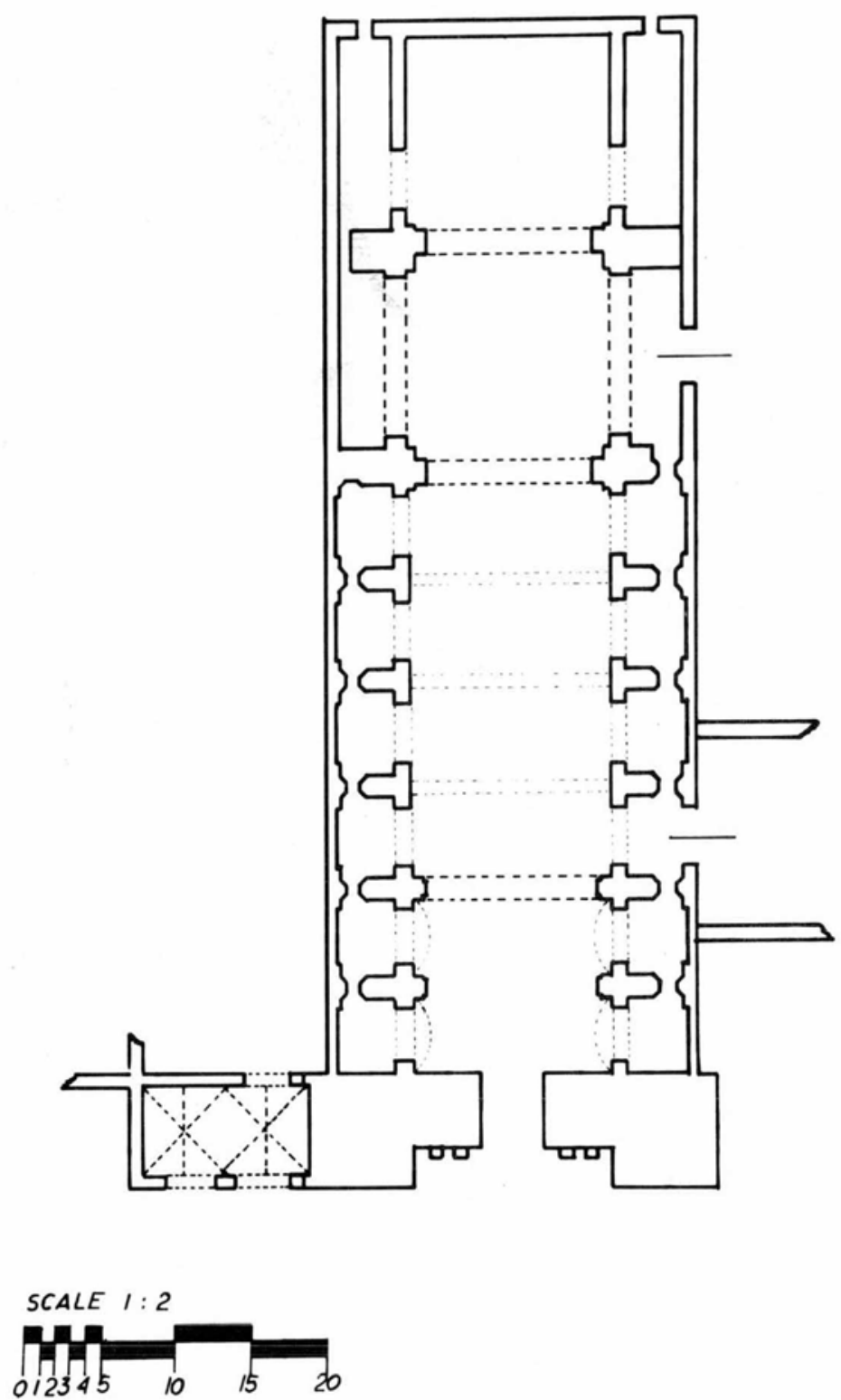

10. Santo Domingo Oaxaca. Plan of church. 


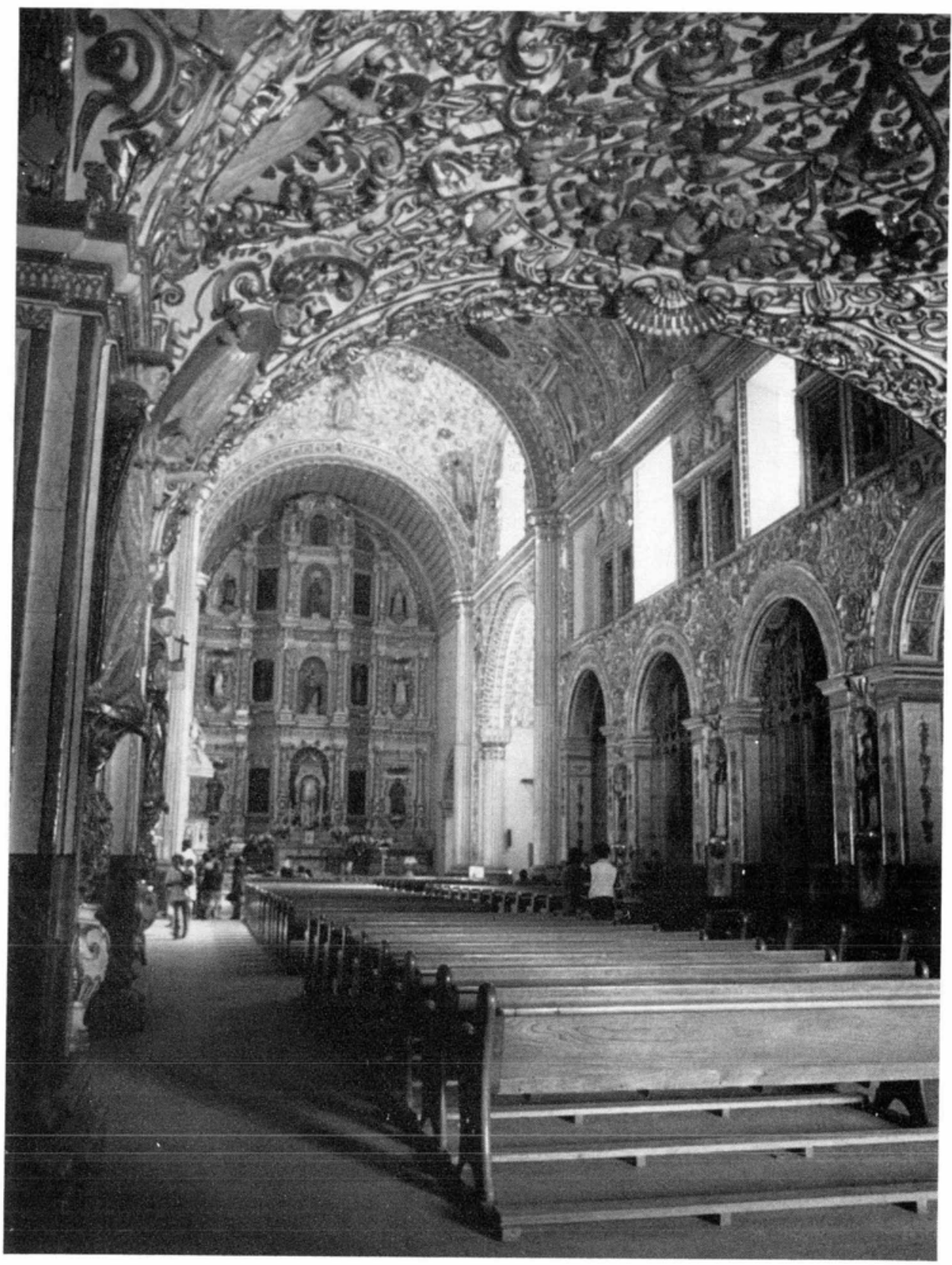

11. Santo Domingo Oaxaca. Nave interior looking east towards crossing and (south) side chapels. 


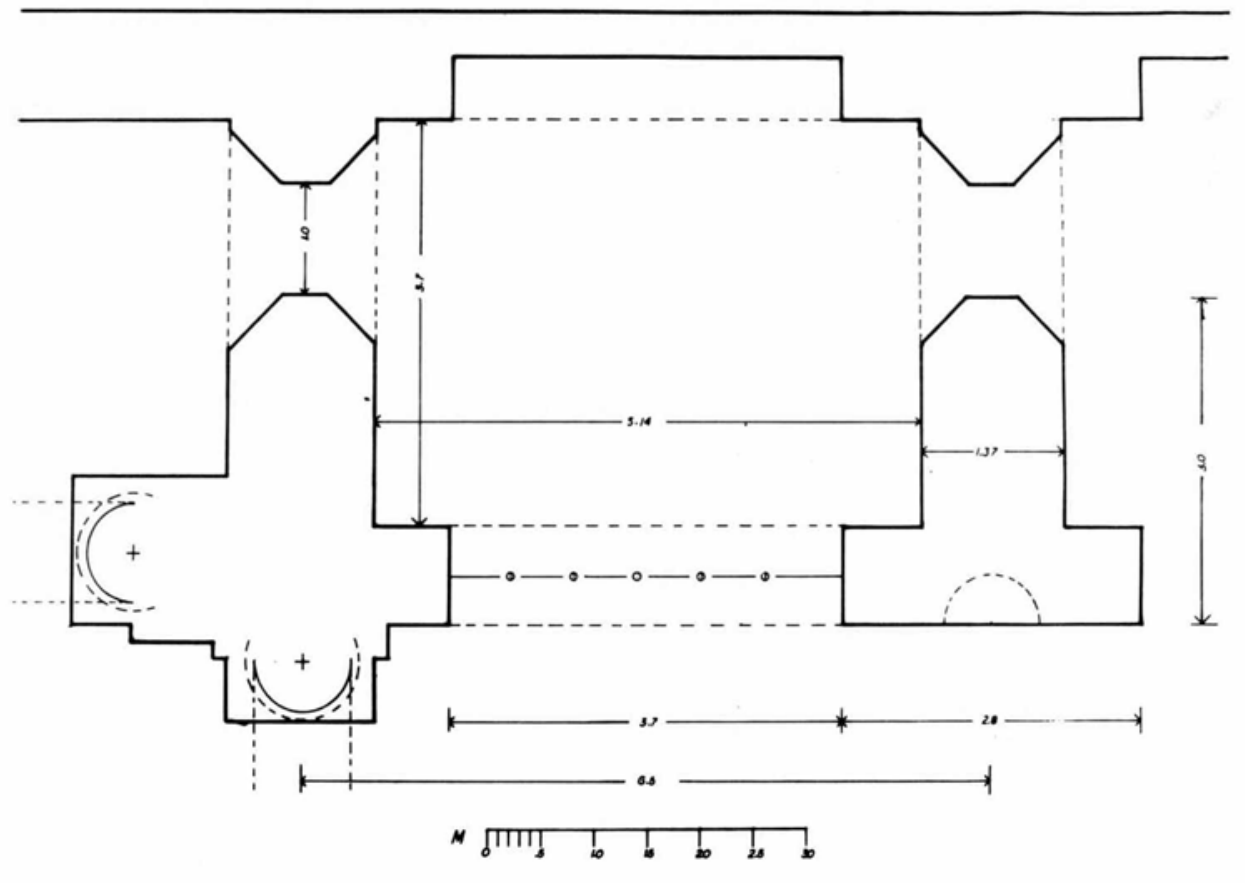

12. Santo Domingo Oaxaca. Detail, plan of crossing pier and side chapel. 


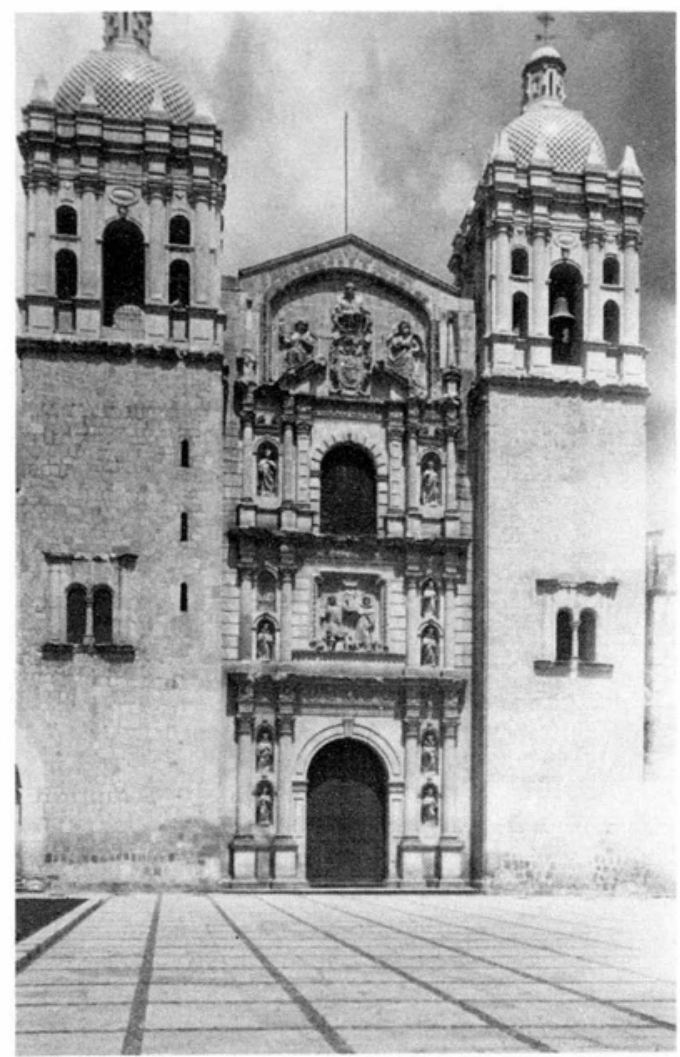

13. Santo Domingo Oaxaca. West front with belfries, facade.

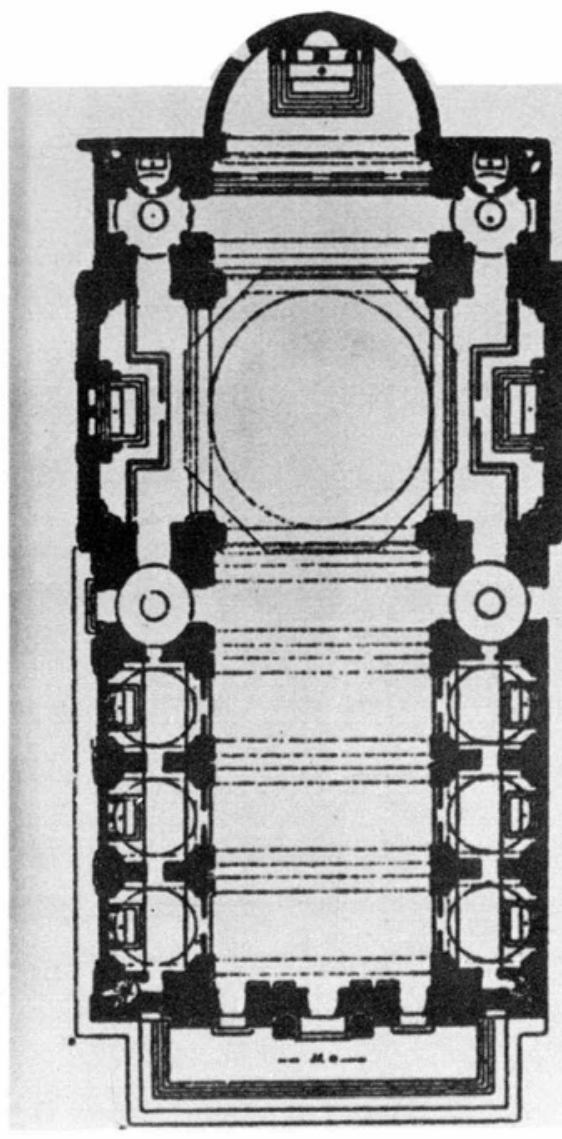

14. Il Gesu Rome. Plan. 
The width of the west front is 24 meters; towers are each 5.5 square. Slightly recessed between them is the facade, measuring $22 \times 13$ (less the crest). The surprise of the past decade is the discovery that this is the second facade. (The 1975 discovery was published in 1978 along with drawings. ${ }^{5}$ ) Even the towers are sheathed with an additional layer of stone. Obviously the original facade was set much deeper between somewhat narrower towers. The choir window, now a rectangle, originally was circular.

The transept-less interior (fig. 3) measures 74.5 meters in length, 14.5 in width and 26 in height, giving it a ratio of 1:5. At eye level the nave, stretching 67.5 meters from west wall to triumphal arch, appears to be unbroken. Its division into four bays is not easily perceived. Only once do engaged columns rise from floor to vault spring - at the juncture of bays three and four. The uninterrupted volume of the nave is impressive in its immensity.

Each bay vault has a complex pattern of ribs. Seven rise from the corner imposts, thirteen from the others. Each impost is seated upon a massive corbel (fig. 4). The tiered cornice, the wide band set off at its top with dentils and at its bottom with a sharply cut molding - all wrapped drumtight around the core of the corbel - with the lower part tapered into three diminishing rings, easily distinguish this architectural moment. It is the "Dominican" corbel (found in a number of Dominican complexes in Oaxaca).

The stone vaults have varying spans. The longest, the diagonal rib, is 23 meters; the shortest, the transverse rib, is 15 . Even though pointed, the transverse rib does not rise to the height of the diagonal rib. The result is a vault with a "domical" shape. Consequently the exterior of each vault, closed with brick, is a bulbous dome giving the roof an undulating pattern.

The nave ends with a superb triumphal arch whose frames extend well out from its walls. Beyond, the considerably narrower sanctuary is closed with a spherical vault, ribbed and coffered. A magnificent "retablo" by Andrés de Concha fills the interior, ${ }^{6}$ all of which is enclosed by a 25 -meter high semicircular apse (fig. 5).

${ }^{5}$ Luis Brozon Mac Donald, "La primitiva portada de la iglesia del convento de Santo Domingo de Yanhuitlán, Oax.", Monumentos Históricos, Boletín núm. 1, Instituto Nacional de Antropología e Historia, Mexico, 1978.

${ }^{6}$ Since the contract between Andrés de Concha and the Dominicans for the retablo was entered into sometime between 1568 and 1570 , the vaulting of the sanctuary can be placed around 1570. Dominican Architecture, p. 139. 


\section{San Juan Bautista Coixtlahuaca}

Fray Francisco Marín was assigned to Coixtlahuaca in 1546. Two years later the pueblo was officially "accepted" by the Order. This means that San Juan Bautista, the parish church, was underway at least by 1548 . Sixteen years later, in 1564, a chapter meeting was held there. ${ }^{7}$ Church and residence would then have been nearing completion. The parish church of San Juan Bautista ${ }^{8}$ sits upon a raised platform.

Facing west, the facade (fig. 6) is set deep between massive square tower bases executed in ashlar. The shell-capped niches to either side of the door are relatively small (creating doubt about any intention to fill them with statues). Enframed in the pediment of the portal is the coat of arms of Philip II, a masterpiece of tequitqui sculpture. Here the choir window is circular. An inscription courses along the entire length of the first tier entablature. To the right the date 1576 has been engraved. (The sharply etched raised disk in the spandrel displays the emblem of the Dominican Order.) The facade, then, was completed some 28 years after church construction began. Executed in a very Renaissance manner this, the original facade, gives us some idea of what Yanhuitlán's might have looked like.

San Juan also boasts a remarkable north door (fig. 7), its window a duplicate of that in the facade. If the master of Yanhuitlán's north door was familiar with the contemporary architectural and sculptural tastes of Spain, not so this artist. The three figures of San Juan Bautista (center), San Pedro (left) and San Pablo (right) are suspended, floating, flat figures with odd anatomical arrangements. The rendering of the inscription around San Juan indicates little familiarity with Roman letters. One " $A$ " bears a strong resemblance to the Mixtec year sign. To the left of this portal are the remains of the once vaulted open-air chapel. Like Yanhuitlán the atrio lies mainly to the north.

In plan (fig. 8) San Juan is a single nave church with four bays and a polygonal apse. The open-air chapel is to the north, the convento to the south. Measurements are impressive: the church is $63 \mathrm{x} 20$ meters; the convento, mostly in ruins, is $54 \times 55$; the facade occupies 12.8 of the 22 meter west front.

Without a triumphal arch, the four-bay nave terminates in an elevated sanctuary (fig. 9). Domical five-ribbed star vaults close each of the four bays.

\footnotetext{
${ }^{7}$ Dominican Architecture, pp 29, 98.

${ }^{8}$ The Dominicans were in charge of San Juan and its many dependencies until 1906. It remains a parish.
} 
Even in their weak definition there are parallels to Santo Domingo in Yanhuitlán. Only in the fourth bay, that adjoining the sanctuary, does a flat pier reach from floor to spring "At the other bays "extruded" corbels, descending to the level of spring of the barrel vaults closing the chapels, carry the sprout of nine ribs. Only the second and fourth bays have wheel ribs at their apex. The first and third terminate in a large boss.

At eye-level only the bay nearest the sanctuary is defined to ground level. In this respect the naves of Yanhuitlán and Coixtlahuaca are quite similar. However, unlike Yanhuitlán, each bay is flanked by a niche, 2.4 deep and 11.9 meters long. The arcaded nave openings have the same 11.9 span. These "chapels," formed by interiorized buttresses, are not inter-connected Each is closed with a barrel vault whose axis is perpendicular to the nave. As in Yanhuitlán, a vaulted choir loft occupies the first bay. Against the 61-meter length of the interior, the 13-meter width of the nave proper creates a ratio of $1: 4.7$.

A gilt retablo virtually conceals the shape of the solid ashlar polygonal apse, but above it twelve ribs and vaulting, forming the apse closure, are visible.

\section{Santo Domingo Oaxaca}

While Yanhuitlán and Coixtlahuaca were centuries-old Mixtec communities, the city of Oaxaca was founded in 1532 "Accepted" by the Order in 1535, the original Dominican establishment in Oaxaca was San Pablo. Inadequate in many regards, the present Santo Domingo eventually replaced it.

Fray Francisco was in Oaxaca from 1547 to 1548 when, presumably, he "drew up the plan" for Santo Domingo. The first Chapter meeting in Oaxaca occurred in 1574 but it is not clear if this took place in San Pablo or Santo Domingo. That it could have been the latter is suggested by the date "1575" inscribed over the entrance into its convento.

Close to the center of the city the complex of Santo Domingo covers almost a square block. Principal components are: the church, measuring $78 \times 25$ meters; to the east; hospital and guest quarters occupying $40 \times 100$; adjoining the church to the north, the residence (convento) for the friars at $57 \times 60$; and, to its north, an $85 \times 77$-meter residence for the novices. It functioned in this manner until ex-claustration in 1859.

A close view of the plan of the church (fig. 10) shows it to be a solid rectangle enclosing choir, nave, side chapels, crossing, transepts, and sanctuary. The interior measurements, from wall to wall, are 66 by 22.5 , a 
ratio of $1: 2.9$. However, the lateral chapels are effectively concealed by piers and screens.

The nave (fig. 11) is organized into six rectangular bays, the choir occupying the first two. Every two bays form a square of $13.2 \times 13.2$. Each nave bay is then divided by a small arch into two rectangles of $6.5 \times 13.2$, This same $13.2 \times 13.2$ unit is found in the sanctuary. Given this nave width the ratio now becomes $1: 5$, the "classic" ratio for single-nave churches.

The crossing and transepts were a challenge. The depth of the transept was restricted by the coterminus convento wall and could not, therefore, reach the ideal "one-half width of the nave." Furthermore the crossing, by definition a square, had to be larger than the rectangle of the nave bay. To create a square the centers of the crossing piers were set at 14.5 meters.

The base circumference of the crossing vault extends beyond the plane of the crossing square. Hence there is no drum. With windows being impractical in this domical vault the only remaining way to illuminate the area of the crossing was to place windows in the transept lunettes, but above their barrel vaults. This required lower crossing arches. Accordingly, the span of the arches to the shallow transept vaults was reduced by 1.16 meters.

There remained the problem of the nave and sanctuary barrel vaults. Since the crossing vault would rise well above them fray Francisco reduced the span of the nave and sanctuary crossing arches by 1.5 meters (to 11.7). By lowering their height he thereby created "proper" triumphal arches.

The solution to this involved structural problem resulted in a distinctive pier-buttress column design for the crossing positions (fig. 12). Its irregular shaped base, a good meter high, is 1.37 wide on the nave side, projecting into the nave $75 \mathrm{~cm}$. The transept side echoes the nave side but, to accomodate the even shorter radius of the transept arches, that pedestal projects another 58 centimeters.

Extending out from the nave wall are interiorized buttresses $(1.37 \times 3.7)$. These form chapels, six to a side, each 5.14 x 3.7 Interconnected by nariow passageways, they provided a private space for friars to say Mass. Clearly the area normally given to aisles was never designed to be processional.

It is evident that, from the outset, fray Francisco intended Santo Domingo to be closed with barrel, not ribbed, vaults. To that end he created the massive nave piers $(2.8 \times 0.90)$ and buttresses to bear the weight of the continuous nave vault. To counter its thrust he set the barrel vaults

\footnotetext{
${ }^{9}$ Kubler, Mexican Architecture, vol.1, p. 242
} 
of the chapels at right angles thereto. By converting aisles into side chapels, and by narrowing their nave entrances, a single nave church was visually created.

The belfried west front measures 27.2 meters in width and even more so in height. Set back 2.5 meters from the frontal plane of its tower bases the four-tiered facade is one-half its width. The $1-2.5-1$ rhythm of the towerfacade-tower west fronts at Yanhuitlán and Coixtlahuaca is changed by fray Francisco to $1-2-1$ here in Oaxaca. With relatively more massive towers ( 7 meters square), he made the west front truly monumental

Even though firm construction dates remain elusive it is certain that Santo Domingo was constructed, in all its essentials, during the last half of the 16 th century. Although parts of the complex have taken on different usages, i.e. the convento is now a handsome regional museum and the novitiate quarters are now army quarters, the sixteenth-century plan remains intact. The Dominicans, who returned in the 1930's, now reside in the former hospital. The church has had three minor alterations: on the south side the Rosary Chapel has been added off the third bay and a new entrance formed out of the sixth bay; on the north side the original entrance into the church from the convento through the transept has been closed.

\section{Analysis}

The design sequence from rib- to barrel-vaulted nave churches would seem to be: Yanhuitlán, Coixtlahuaca, and finally Santo Domingo in Oaxaca. Dimensions are impressive - lengths, respectively, of 79, 63 and 78 meters. All are clearly by the same hand, works of an inspired architect.

In Santo Domingo Yanhuitlán fray Francisco Marín reflects the style then popular in Spain of continuous-nave, transept-less, churches with $1: 5$ ratios. Its most impressive feature is the tremendous volume of the virtually undemarcated nave. Ribbed vaults and classic entablatures reflect the uneasy Gothic-Renaissance marriage being experienced in 16th-century Spain.

At San Juan Bautista Coixtlahuaca fray Francisco introduced interiorized buttresses, jutting out from the walls at 12-meter intervals. The four ribvaulted nave bays thereby became 12-meter squares with "appendages". These, however, are not interconnected; access is from the nave through arches with a 11.8 span. The Gothic-Renaissance spirit still lingers.

In Santo Domingo, Oaxaca, Marín becomes a full-fledged Renaissance architect. Beneath the almost overwhelming impact of the glittering white and gold stucco covering all interior surfaces lies the evidence. Barrel vaults 
have replaced ribbed vaults. The apse is squared. The aisles become side chapels. The nave side of the latter is given a wide face reducing the entrance width into the chapels to 3.65 meters. The smaller nave arches and wider "piers" create the effect much more of a pierced wall than an arcade.

The "Dominican" corbels, once massive statements supporting a haunch of rib vaults, now give way to modest capitals (on engaged fluted columns) which, however, echo the "trademarks" of Marín's corbels. Now the interior has been transformed into a broad single nave with defined bays, a large domed crossing, shallow transepts and a squared sanctuary.

Vignola is universally acclaimed for his dynamically new design changing the three-aisled basilica into a single nave church. Il Gesu, says Kostov, presents "a broad, barrel vaulted nave flanked by a series of subordinate chapels, a shallow transept with a dome over the crossing...., ${ }^{10}$ a description which fits Santo Domingo equally well. II Gesu was started in 1568. If Santo Domingo was started soon after fray Francisco Marín's stay in Oaxaca from 1547 to 1548 , then his design anticipates Vignola's by almost twenty years!

Where did fray Francisco Marín acquire his remarkable skills? What accounts for his transformation from a "Gothic" to "Renaissance" architect? In all likelihood from Rodrigo Gil de Hontañón. The SAH Journal of December 1982 has this to say: "...aside from the more theoretical writings of Leonardo da Vinci, the work of Rodrigo Gil is the principal evidence extant for the development of structural thinking among 16-th century master masons"."1

This influential Spanish architect, practioner and theoretician, was adopting the Renaissance style by 1533 . He was associated with the Dominicans in Spain for more than 50 years - from at least the 1520 's to $1577 .{ }^{12}$ Fray Marin is first recorded in Mexico in 1538. Before leaving Spain he would have had both the time and occasion to become familiar with Rodrigo Gil's formulae. That of buttress depth to span ratio may well have been applied by fray Francisco.

The accomplishments of fray Francisco Marín are extraordinary, especiaily under the difficult circumstances of language and cultural barriers. Skilled as the native artisans weres, they had never before enclosed such volumes nor covered them with vaults. To those accomplishments already cited must

${ }^{10}$ Spiro Kostov, A History of Architecture (Oxford, 1985), p. 513

${ }^{11}$ Sergio L Sanabria, "The Mechanization of Design in the 16th Century: The Structural Formulae of Rodrigo Gil de Hontañon," Journal of the Society of Architectural Historians, December 1982, vol. XLI, number 4, p. 281.

${ }^{12}$ The link between Rodrigo Gil de Hontañón and the Dominicans in Spain is examined at length in Dominican Architecture, Chapter 7. 
be added a work considered by many to be the crowning architectural glory of sixteenth-century Mexico. Teposcolula's open air chapel (fig. 14) was started by fray Francisco in 1549 and completed a few years later. ${ }^{13}$ It was Marín's fate to practice his profession in "New" rather than "Old" Spain. Had he worked there he surely would be ranked among the great architects of the Renaissance. It is time that the genius of fray Francisco Marín, hidden for over four centuries, be revealed.

${ }^{13}$ Dominican Architecture, p. 138. 